\title{
Eksamen er et komplekst fænomen
}

\author{
Anmeldelse af Merete Wiberg, Institut for Uddannelse, Laring og Filosofi, Aalborg Universitet
}

Eksamen og Eksamensformer

Hanne Leth Andersen og Jens Tofteskov

Samfundslitteratur

2008

171 sider

ISBN: 978-87-593-1412-8

Bogen Eksamen og eksamensformer, som er skrevet af Hanne Leth Andersen, professor i universitetspædagogik ved Aarhus Universitet og Jens Tofteskov, pædagogisk konsulent ved CBS, henvender sig til uddannelsesplanlæggere, undervisere og censorer. Bogen tjener to formål: Dels giver den et indblik i forhold omkring eksamen, og dels diskuterer den mere grundlæggende aspekter vedrørende eksamens betydning og funktion i uddannelsessystemet.

Således indeholder bogen analyser og diskussioner af et bredt spektrum af forhold omkring eksamen, herunder sammenhæng mellem eksamensformer og læring, eksameners validitet og reliabilitet, karaktergivning og vurdering på baggrund af taksonomier, eksamensformers autenticitet samt diskussioner af, hvordan politiske forhold spiller ind på eksamenstænkning og eksamensformer. Bogen indeholder 3 dele. Første del omhandler generelle overvejelser vedrørende eksamen. Anden del er en gennemgang af forskellige eksamensformer, mens tredje del omhandler bedømmelse og votering.

Det er en styrke ved bogen, at den analyserer og diskuterer mere grundlæggende aspekter ved eksamener. Samtidig er bogen tydeligvis en oversigtsbog, hvor der ikke er plads til dybere analyser og diskussioner. F.eks. gennemføres der i kapitlet om taksonomier en analyse af forskellige typer af taksonomier. Der redegøres for den velkendte Blooms taksonomi samt for SOLOtaksonomien. Derudover inddrages Dreyfus og Dreyfus' kompetenceniveauer med henblik på at kunne tilbyde en taksonomi, der vurderer færdigheder. Forfatterne bidrager selv med to taksonomier, der har fokus på henholdsvis rutine og refleksion samt faglig kompleksitet. Det er en god ide at diskutere grundlæggende aspekter ved forskellige typer af taksonomier op imod hinanden, men kapitlet kommer til at fremstå noget ufærdigt, idet der mangler en redegørelse og diskussion af, hvordan de forskellige taksonomier kan bruges i forhold til hinanden, og hvad det erkendelsesteoreti- ske grundlag er for de forskellige taksonomier. F.eks. tilhører Dreyfus og Dreyfus' kompetenceniveauer en anden kategori end Blooms og Biggs taksonomier. Også refleksionsbegrebet som forfatterne bruger som omdrejningspunkt for udfærdigelsen af en taksonomi mangler en grundigere behandling.

Vigtig er bogens gennemgående diskussion om eksameners gyldighed og reliabilitet. Forfatterne har udfærdiget et skema, som viser forholdet mellem gyldighed, reliabilitet, økonomi og eksamensformer. Multiple choice har lav gyldighed, men høj reliabilitet, mens en projekteksamen har meget høj gyldighed, men lav reliabilitet. Skemaet giver et godt overblik og er en god overgang til bogens anden del vedrørende eksamensformer. Der kunne dog i højere grad henvises til undersøgelser vedrørende forholdet omkring reliabilitet og validitet. Forfatterne gør i øvrigt selv opmærksom på det problematiske $i$ at foretage opdelingen mellem reliabilitet og validitet. Det er en styrke ved bogen, at der konstant gøres opmærksom på, at eksamen er et meget komplekst fænomen, som kræver hensyntagen til mange forskellige forhold.

Del 2 indeholder en gennemgang af forskellige eksamensformer. Der redegøres for et meget bredt spektrum af eksamensformer - fra mundtlig og skriftlig eksamen til casebaserede eksamener, projekteksamener og portfolioeksamen. Løbende diskuteres de forskellige eksamensformers fordele og begrænsninger i forhold til, hvordan eksamen influerer på undervisning og læring. Interessant er diskussionen vedrørende fagfællebedømmelse, dvs. de studerendes vurdering af hinanden, samt den aktuelle diskussion vedrørende gruppearbejde og evaluering af dette.

I del 3 diskuteres bedømmelse og votering. I denne sammenhæng peges der blandt andet på, at undervisere og censorer mangler formel kompetence til at gennemføre eksamen. Dette er en væsentlig anke mod eksamensinstitutionen, og forfatterne har ret $i$, at der i højere grad burde finde en opkvalificering sted på dette område.

Bogens styrke er, at den på nuanceret vis kommer vidt omkring et bredt spektrum af forhold vedrørende fænomenet eksamen og dette fænomens betydning for læring og uddannelse. En svaghed er, at om end der 
er henvisninger til undersøgelser vedrørende eksameners betydning og validitet, så inddrages disse kun i begrænset omfang, hvilket betyder, at de mange gode råd vedrørende eksamensplanlægning og afholdelse netop kommer til at fremstå som gode råd, idet videnskabelige undersøgelser og teoretiske diskussioner er nedtonet. Begrundelsen herfor kan være den ganske rimelige, at bogen er tænkt brugsrettet og i et anvendelsesøjemed, og ikke med sigte på en dybtgående undersøgelse af forhold omkring eksamen. Samtidig skal det siges, at bogen udmærker sig ved, at den i og med, at de grundlæggende diskussioner tematiseres, giver læseren incitament til at give sig i kast med de mere grundlæggende diskussioner vedrørende eksamen.

Bogen burde være obligatorisk læsning for uddannelsesplanlæggere, eksaminatorer og censorer. Eksamen er en meget vigtig del af de studerendes studieliv og kan have vidtrækkende konsekvenser for deres karrieremuligheder. I forhold til et planlægningsperspektiv yder bogen også god hjælp, og den kan forhåbentlig bidrage til en større variation i eksamensformer på de enkelte uddannelser og dermed en mere nuanceret samlet vurdering af de studerende. 